\title{
Jan Chłosta \\ SPRAWOZDANIE Z OBCHODÓW 90 ROCZNICY UTWORZENIA POLSKICH SZKÓŁ NA WARMII I MAZURACH
}

Na wniosek posłanki na Sejm Urszuli Pasławskiej 23 marca 2019 r. Sejmik Województwa Warmińsko-Mazurskiego podjął uchwałę o uznaniu 2019 Rokiem 90-lecia szkół polskich na Warmii i Mazurach. Skłoniło to olsztyńskie instytucje kulturalno-oświatowe i towarzystwa naukowe jak: Wojewódzką Bibliotekę Publiczną, Muzeum „Gazety Olsztyńskiej”, Stowarzyszenie Przyjaciół Filatelii Maltańskiej oraz Instytut Północny i Towarzystwo Naukowe im. Wojciecha Kętrzyńskiego do podjęcia wielu inicjatyw upowszechniających rolę i znaczenie polskich szkół w aktywizacji ruchu polskiego na tych ziemiach w latach międzywojnia. Sprowadzały się one do rozpisania konkursu fotograficznego, urządzenia wystaw okazjonalnych, edycji szeregu wydawnictw oraz odbycia spotkań we wsiach, gdzie w latach 19291939 znajdowały się polskie szkoły.

Obchody 90-lecia szkół polskich, rozpoczęte zostały 20 lutego 2019 r. roboczą naradą pod przewodnictwem członka Zarządu Województwa Warmińsko-Mazurskiego p. Sylwii Jaskulskiej z udziałem przedstawicieli wymienionych wyżej instytucji oraz wicestarosty powiatu olsztyńskiego p. Joanny Michalskiej. Ustalone zostały zakresy działań. Podkreślono przy tym potrzebę upowszechniani znaczenia tych szkół w mediach.

Same obchody rozpoczęto 19 września 2019 r., w sali konferencyjnej nowego skrzydła WBP w Olsztynie konferencją: Szkoły polskie na Warmii i Mazurach 19292019. Współorganizatorami jej były: Towarzystwo Naukowe im. W. Kętrzyńskiego w Olsztynie oraz Urząd Marszałkowski Województwa Warmińsko-Mazurskiego (Departament Kultury i Edukacji). Podczas konferencji zaprezentowano referaty: Od polskich szkól do polskiego uniwersytetu w Olsztynie - prof. dr hab. Stanisław Achremczyk, Losy nauczycieli szkół polskich - dr Jan Chłosta, Uczniowie szkól polskich - życiowe perypetie - mgr Danuta Syrwid, Pamięć o szkołach polskich dzisiaj - dr Iwona Jóźwiak. Referaty pokonferencyjne zostały przekazane organizatorom 
w formie artykułów do dalszej publikacji. W ramach jubileuszu, we współpracy z Towarzystwem Naukowym im. W. Kętrzyńskiego oraz Stowarzyszeniem Przyjaciół Filatelii Maltańskiej, podczas wydarzenia zaprezentowano liczne wydawnictwa okolicznościowe: po raz pierwszy wykonaną mapą powiatu olsztyńskiego z naniesionymi budynkami szkół polskich oraz fotografiami nauczycieli tych szkół; pieczęcie z wizerunkiem Domu Polskiego i fotografią Marii Zientary-Malewskiej na jubileuszowych zakładkach; tekę z pocztówkami i kalendarz okolicznościowy, a także przygotowaną przez Departament Kultury i Edukacji Urzędu Marszałkowskiego wystawę Szkoły polskie na Warmii i Mazurach 1929-1939 w obiektywie. Podczas komunikatów zaprezentowano książkę Kronika katolickiej szkoły polskiej $w$ Nowej Kaletce ze wstępem i w opracowaniu J. Chłosty oraz na kilku spotkaniach inicjatywę konkursową $16 \times 90$ Wojewódzkiej Biblioteki Publicznej w Olsztynie.

Wojewódzka Biblioteka Publiczna w Olsztynie zorganizowała konkurs historyczno-fotograficzny pt. $16 \times 90$ pod patronatem honorowym Marszałka Województwa Warmińsko-Mazurskiego. Nazwá wydarzenia nawiązuje do 16 szkół polskich w regionie (15 na Warmii i 1 na Mazurach w Piasutnie). Konkurs miał na celu zainteresowanie mieszkańców naszego województwa historią tych placówek, przypomnieć nauczycieli, działaczy kultury, a także mieszkańców kilkunastu małych miejscowości, którzy zasłużyli się w trwania przy polskiej kulturze na Warmii i Mazurach.

Formuła konkursu, jaką była praca fotograficzna inspirowana działalnością szkół polskich na Warmii i Mazurach w latach 30. XX w., miała zachęcić do udziału szczególnie młodzież i starsze dzieci, które na co dzień posługują się nowoczesną technologią i korzystają z mediów. W ramach projektu w czerwcu 2019 r. założona została strona internetowa: https://16x90.home.blog, na której zamieszczono do końca trwania naboru prac kilkadziesiąt wpisów historycznych o szkołach polskich na Warmii i Mazurach, informacje, ciekawostki i materiały wizualne na temat wszystkich 16 szkół polskich, a także galeria nauczycieli oraz polecana literatura o Warmii okresu międzywojennego. Strona stała się tym samym miejscem edukacji historycznej i inspiracji fotograficznych, a po zakończeniu konkursu pozostała źródłem wiedzy dla nauczycieli i zainteresowanych. Ze względu na przyjętą w konkursie formę fotografii instagramowej, popularnej w mediach. 6 sierpnia 2019 r. zorganizowano warsztaty „Fotografia FLAT LAY w teorii i praktyce”, na których odbyły się prezentacja i warsztaty fotograficzne $\mathrm{z}$ techniki flat lay, mające na celu przybliżenie techniki prac wymaganych w konkursie historyczno-fotograficznym"16x90".

Zadaniem konkursowym było stworzenie wizualnej opowieści o historii jednej z wybranych szkół polskich, z zastosowaniem pamiątek, fotografii, doku- 
mentów, własnoręcznie przygotowanych prac, ale też przedmiotów codziennego użytku, roślin i wielu innych dostępnych rekwizytów, co pozwoliło nie tylko ukazać klimat przedwojennej szkoły, ale i w sposób plastyczny, bez użycia tekstu, wyrazić treści i odczucia związane z poznaną historią.

Na konkurs wpłynęło kilkanaście prac w kategorii osoby niepełnoletnie oraz w kategorii osoby pełnoletnie. W październiku 2019 r. uruchomiony został Instagramowy konkursowy jako platforma prezentacji prac z warsztatów i prac nadesłanych na konkurs. Komisja konkursowa w składzie: Iwona Jóźwiak (historyk, nauczyciel) - Przewodnicząca Komisji, Jarosław Poliwko (fotografik), Grzegorz Wadowski (fotograf i nauczyciel) w pierwszym tygodniu października 2019 r. wyłonili w konkursie laureatów dwóch nagród głównych (tablety) oraz dwóch nagród specjalnych (autorskie projekty stanowiły okładkę 700 zeszytów szkolnych) i wyróżnień (książki o tematyce historycznej i fotograficznej oraz edukacyjne gry planszowe). Uroczyste wręczenie nagród oraz pamiątkowych dyplomów nastąpiło 8 listopada 2019 r. podczas wydarzenia pt. „Dążąc do polskości”. Spotkanie to zorganizowano $w$ formie konferencji regionalnej skoncentrowanej wokół historii i kultury przedwojennej Warmii, w tym pracy nauczycieli, działaczy, wydawców i dziennikarzy jednego $\mathrm{z}$ największych regionalnych dzienników oraz jego roli w podtrzymywaniu polskości na Warmii i Mazurach. W programie znalazły się:

1. Podsumowanie konkursu $16 \times 90$ : prezentacja strony internetowej dedykowanej tematyce obchodów 90-lecia szkół polskich na Warmii i Mazurach (Anita Romulewicz), zaprezentowanie wyników konkursu (przewodnicząca Komisji konkursowej dr I. Jóźwiak) oraz wręczenie nagród laureatom konkursu (Marszałek Województwa Warmińsko-Mazurskiego);

2. Kolekcja przedwojennej „Gazety Olsztyńskiej” za lata 1886-1914 w WBP w Olsztynie (Dyrektor WBP w Olsztynie Andrzej Marcinkiewicz); Archiwum „Gazety Olsztyńskiej” w Warmińsko-Mazurskiej Bibliotece Cyfrowej (Anna Rau); panel dyskusyjny na temat historii, celów i działaczy regionalnych związanych z „Gazetą Olsztyńską".

W dyskusji wzięli udział: Jan Chłosta regionalista, znawca historii Warmii, wiceprezes Towarzystwa Naukowego im. W. Kętrzyńskiego w Olsztynie, Danuta Syrwid historyk, kustosz Domu „Gazety Olsztyńskiej” Muzeum Warmii i Mazur, badaczka przedwojennego dziennika, Igor Hrywna, redaktor naczelny współczesnej „Gazety Olsztyńskiej”. Rozmowę prowadziła redaktor Ewa Zdrojkowska - dziennikarka Radia Olsztyn). Uczestnicy spotkania otrzymali wydane w konkursie zeszyty okolicznościowe oraz zakładki z adresem domeny Warmińsko-Mazurskiej Biblioteki Cyfrowej. Wydarzeniu towarzyszyła wystawa pt. Szkoły polskie na Warmii i Mazurach 1929-1939 w obiektywie oraz ekspozycja dokumentów życia społecznego związanych z historią „Gazety Olsztyńskiej”. Uczestnicy konferencji 
otrzymali zeszyty pokonkursowe, z których większość trafiła do placówek bibliotecznych. W 2020 r. część zeszytów upamiętniających nauczycieli w Wymoju trafiła do Zespołu Szkół Szkolno-Przedszkolnych w Stawigudzie w planowanym konkursie szkolnym z okazji plebiscytów na tych ziemiach

Ważne były działania podejmowane w ramach obchodów przez Muzeum Warmii i Mazur. Łączyły się one z opracowaniem prezentacji multimedialnych: Szkolnictwo polskie na Warmii i Mazurach 1929-1939 oraz Olsztyn: Czyje imię nosi ta ulica? Godzi się w tym miejscu przypomnieć, że wielu nauczycieli polskich szkół obrano patronami olsztyńskich ulic, m.in. Bolesława Jeziołowicza, Edwarda Turowskiego, Józefa Grotha, Ryszarda Knosały, Jerzego Lanca, Marii Zientary-Malewskiej.

Urządzono również specjalną „Niedzielę w Muzeum” z wystawą: Przyznając się do polskości. Szkoły polskie na Warmii i Mazurach (29 września 2019 r.) wraz z warsztatami edukacyjno-plastycznymi, a w nich $\mathrm{m}$. in. rozwiązywanie rebusów tematycznie związanymi z polskimi szkołami z lat międzywojnia. Zadbano też o promocję dziejów polskich szkół na banerze internetowym „Olsztyn24”, informacjach Starostwa Powiatowego w Olsztynie, Urzędu Marszałkowskiego Województwa Warmińsko-Mazurskiego oraz Kuratorium.

Również planszowa wystawa przygotowana przez Muzeum, poświęcona tamtym szkołom i ich nauczycielom, była eksponowana w Instytucie Północnym im. Wojciecha Kętrzyńskiego w Olsztynie, miejscowym Zespole Placówek Edukacyjnych, ostródzkim Hufcu Związku Harcerstwa Polskiego, szkołom w Świętajnie, w dawnej szkole polskiej w Pluskach.

W trakcie obchodów Marszałek Województwa Warmińsko-Mazurskiego Gustaw Marek Brzezin skierował do przedstawicieli rodzin, związanych ze szkołami specjalny adres z podziękowaniem za podjęty trud w upowszechnianiu znaczenia tamtych szkół w zachowaniu kultury polskiej na południowej Warmii. Takie listy otrzymali: Jadwiga Piskorska, Tadeusz Pacer, Wanda Czerwińska, Marian Barcz, Robert i Henryk Pieczkowscy, Maria Anielska, Anna i Roch Mackowiczowie, Maria Surynowicz, Elżbieta Pimpicka, Aniela Jadwiga Ferenc, Andrzej Frenszkowski.

Odbyły się spotkania we wsiach pod Olsztynem w Spręcowie w gminie Dywity połączona z nadaniem miejscowej szkoły patrona ks. Walentego Barczewskiego (6 czerwca 2019 r.). Tego samego dnia odbyło się w Sali Wojewódzkiej Biblioteki Publicznej posiedzenie Komisji Kultury Towarzystwa Naukowego im. W. Kętrzyńskiego, na którym Prof. dr hab. Izabela Lewandowska przedstawiła biografię współzałożyciela i opiekuna polskiej szkoły w Jarotach (obecnie dzielnica Olsztyna) Józefa Malewskiego, natomiast mgr Radosław Batożyński wraz z Markiem Wąsikiem - dyrektorem Szkoły Podstawowej nr 34 im. Józefa Malewskiego w Olsztynie zaprezentowali współczesne działania edukacyjne w celu popularyzacji tej postaci. Pokazano też przygotowaną do druku biografię J. Malewskiego. W części wspo- 
mnieniowej Tadeusz Pacer na podstawie fotografii i kroniki rodzinnej przestawił działalność pedagogiczną swojego ojca i całego polskiego środowiska. Prezentacja Tadeusza Pacera, zawierająca bogaty materiał ilustracyjny została przekazana do zbiorów WBP w Olsztynie. W spotkaniu udział wzięli byli uczniowie szkół, ich bliscy, nauczyciele i dyrektor Szkoły Podstawowej w Jarotach, historycy, badacze regionu. Zaprezentowana została prezentacja filmowa, multimedialna, pamiątki, wspomnienia. Kolejne spotkania odbyły się: w Butrynach (24 września 2019 r.), Gietrzwałdzie (26 września), Dywitach (4 października), w Pluskach (6 października). Spotkanie zostało wzbogacone pokazem zarejestrowanych zdjęć z życia tej szkoły, także jej opiekuna Augusta Popławskiego, prezentowanych przez wnuka tego działacza Jerzego Popławskiego oraz wystąpieniem syna nauczyciela tej szkoły Roberta Gransickiego, zamieszkałego obecnie w Gdyni Janusza Gransickiego oraz udziałem w spotkaniu uczennicy polskiej szkoły w Pluskach i Nowej Kaletce Adeli Popławskiej, poza tym w Purdzie (21 października) oraz w Zespole Szkół Ekonomiczno-Handlowych im. Polaków spod znaku Rodła w Olsztynie (23 października). Na tych spotkaniach zaprezentowano następujące tematy:

Uczniowie polskich szkół - portret zbiorowy;

Martyrologia nauczycieli polskich szkół na Warmii i Mazurach po wybuchu II wojny światowej;

- $\quad$ Szkoła polska w Purdzie n tle innych szkół na południowej Warmii;

- Pierwsze cztery szkoły na Warmii (Chaberkowo, Gietrzwałd, Nowa Kaletka, Unieszewo), otwarte 10 kwietnia 1929 r.;

- Warmia w poezji Marii Zientara-Malewskiej, w 125 rocznice urodzin i 35 rocznicé śmierci;

- Ryszard Knosała - harcerz niezłomny;

- Polska szkoła w Brąswałdzie;

- Droga do polskich szkół;

- Historia Domu Polskiego w Olsztynie.

- Nad działalnością Polsko-Katolickiego Towarzystwa Szkolnego na Warmię.

Wymienione tematy przedstawili członkowie Towarzystwa Naukowego im. W. Kętrzyńskiego: prof. dr hab. Anna Pytasz-Kołodziejczyk, mgr Danuta Syrwid, prof. dr hab. Izabela Lewandowska, dr Iwona Jóżwik, mgr Anita Romulewicz, mgr Jerzy Laskowski, mgr Tadeusz Pacer, dr Jan Chłosta. Wszystkie spotkania zostały wzbogacone recytacjami wierszy przez uczniów miejscowych szkół oraz występami chórów i zespołów muzycznych.

Jestem przekonany, że obchody 90-lecia utworzenia polskich szkół na Warmii i Mazurach przyczyniły się do lepszego poznania przez młodzież polskiego trwania w latach międzywojennych na tych ziemiach. 